American Journal of Agricultural and Biological Sciences 6 (3): 418-422, 2011

ISSN 1557-4989

(C) 2011 Science Publications

\title{
Soil Compaction in Sugarcane Fields Induced by Mechanization
}

\author{
Prathuang Usaborisut and Watcharachan Sukcharoenvipharat \\ Department of Agricultural Engineering, Faculty of Engineering at Kamphaengsaen, \\ Kasetsart University, Kamphaengsaen Campus, Nakhonpathom 73140, Thailand
}

\begin{abstract}
Problem statement: Recently in Thailand, the problem of soil compaction, especially associated with more mechanized sugarcane production, has drawn attention from both the government and private sectors. Approach: To understand this problem, investigations of soil compaction using cone penetration resistance and bulk density were conducted in 16 sugarcane fields with 10 fields involving mechanized farming and 6 field's mainly manual labor farming. Results: It was found that the highest bulk density was $1.78 \mathrm{~kg} \mathrm{~m}^{-3}$ with mechanized farming while the lowest value was $1.24 \mathrm{~kg} \mathrm{~m}^{-3}$ in the fields cultivated using manual labor. The average value of soil bulk density samples under mechanized farming was $12.6 \%$ significantly higher than under manual labor. Cone penetration resistance across cane rows could be significantly divided into two layers at a depth of $45 \mathrm{~cm}$, with the lower layer having higher penetration resistance. The average value of penetration resistance under mechanized farming was $23.3 \%$ higher than from manual labor. Cone penetration resistance values exceeded $2 \mathrm{MPa}$, especially for the fields with more years with ratoon canes and in fields subjected to mechanized farming. Under manual labor farming, the soil cone penetration resistance across cane rows showed a pattern of less scattering at depths less than $45 \mathrm{~cm}$. Conclusion: Soil compaction induced by mechanization was clarified to some extent.
\end{abstract}

Key words: Soil compaction, mechanized farming, labor farming, cone penetration, less scattering, important economic, published research

\section{INTRODUCTION}

Sugarcane is one of the most important economic crops in Thailand. In 2008, about 73 million tonnes were produced from about one million hectares, which ranked Thailand third among world producers, after Brazil and China (CAI, 2008). Sugarcane serves as both a food and fuel crop. Ethanol production from sugarcane is consistent with the gasohol promotion policy of the Thai government, which aims to increase domestic ethanol demand to three million liters per day by 2011 (Cane and Sugar Industry Policy Bureau, 2006). In the past, the use of manual labor for sugarcane production was popular due to low labor costs. However, nowadays, mechanization in sugarcane farming is becoming more important due to the everincreasing demand for sugarcane together with the problem of a labor shortage. Grange et al. (2005) reported that a high number of machine traffic passes are used in Thailand, with 13 passes being observed in conventional tillage treatments. Heavy equipment and the intensive use of machinery can cause damage to the soil structure, which is of concern as the structure affects the ability of a soil to hold and conduct water, nutrients and air that are necessary for plant root activity, with sustained damage eventually reducing yields. Soil compaction as a result of mechanization must be considered as one of the negative consequences of sugarcane production. Soil compaction has been identified on $4,364,820$ hectares or $8.5 \%$ of the total area of Thailand (Land Development Department, 2009). Alakukku and Elonen (1995) reported that on average in the first 8 years, compaction of the clay soil with four passes reduced the yields by $4 \%$ and nitrogen uptake of the annual crop by $9 \%$. Usaborisut and Niyamapa (2010) reported that the greatest reduction in the yield of sugarcane compared with a control field was $22.9 \%$, which resulted from compaction following 15 tractor passages. Nowadays, the problems of soil compaction are drawing the attention of both the government and private sectors. The Office of Agricultural Economics of Thailand published research work that showed applying subsoiling helped improve the yield of cassava by up to $15 \%$. Mitr Phol Group (2011) which is a group of companies operating businesses in the cane and sugar industry has posted

Corresponding Author: Prathuang Usaborisut, Kasetsart University, Kamphaengsaen Campus, Nakhonpathom 73140, Thailand Tel/Fax: +6634-351896 
information on its websites to encourage farmers to carry out subsoiling in sugarcane fields. In addition, there have also been several campaigns by a number of provincial governments to address soil compaction in crop fields (Udon-City.Com, 2011). Since soil compaction has been recognized as one of the serious problems of sugarcane farming in Thailand, considerable effort has been applied to clarify the behavior and manage the effects of soil compaction. Firstly soil compaction in sugarcane fields needs to be characterized. Therefore, the aim of the present research was to investigate soil compaction induced by mechanization in sugarcane fields and to compare the compaction with that in field's farmed using manual labor.

\section{MATERIALS AND METHODS}

Investigation site: The study was conducted in 16 sugarcane fields located in central Thailand, where sugarcane production is undertaken on 326,756 hectares of the total area of 1,042,620 hectares (Office of the Cane and Sugar Board, 2008). The soil properties in the 16 fields are categorized in Table 1.

The first 10 fields in Table 1 were subjected to mechanized farming while the remaining 6 fields were cultivated by manual labor, with the exception of tillage that was done by a tractor with a disk plow. Typically, the machinery used in the mechanization cultivation was: a tractor (weighing about $4 \mathrm{t}$ ) with a tillage tool attached for soil preparation; a tractor $(4 \mathrm{t})$ with a sugarcane planter $(0.5 \mathrm{t})$; and a harvester $(15 \mathrm{t})$ and truck with total weight about $30 \mathrm{t}$. The sugarcane is replanted about every three years and five years for the mechanized and manual labor farming systems, respectively. The sugarcane crops in the study fields included plants to the 5th ratoon. In the mechanized farming fields, there were 2, 3, 3 and 2 fields containing planted, 1st, 2nd and 3rd ratoon crops, respectively. In the manual labor fields, there were 1 , 3, 1 and 1 fields containing planted, 1st, 3rd and 5th ratoon crops, respectively. Three-digit field codes were allocated to each treatment, with the first letter specifying the farming method $(\mathrm{M}=$ mechanized farming; L = manual labor farming), followed by a number giving the crop type and the last number identifying the field number.

Data measurement: A cone penetrometer was used to measure the soil resistance in all fields with four samples from each field. Measurements were taken 10 $\mathrm{cm}$ apart across a row of cane for $200 \mathrm{~cm}$ and extended into soil to a depth of $90 \mathrm{~cm}$. The middle of the row was set at the $100 \mathrm{~cm}$ sampling point (Fig. 1). The soil surface profile was also recorded. Samples for bulk density were taken at depths of $20 \mathrm{~cm}$ and $40 \mathrm{~cm}$ using a core soil sampler.

Statistical differences were tested using Duncan's multiple Range Test (DMRT) at the 95\% level.

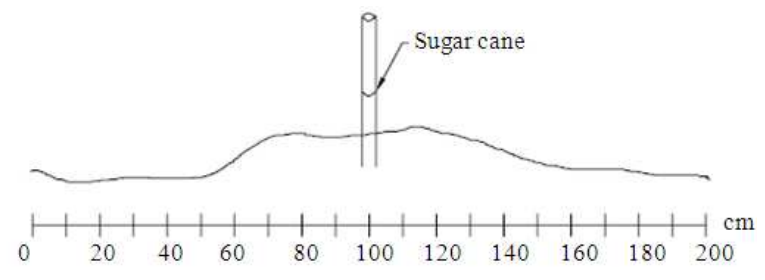

Fig. 1: Location of soil resistance samples in sugarcane row

Table 1: Field specifications and soil properties of study area

\begin{tabular}{|c|c|c|c|c|c|c|}
\hline \multirow[b]{2}{*}{ Field code ${ }^{*}$} & \multirow[b]{2}{*}{ Farming method } & \multirow[b]{2}{*}{ Crop } & \multicolumn{4}{|c|}{ Soil Texture } \\
\hline & & & Sand $(\%)$ & Silt (\%) & Clay (\%) & Soil type \\
\hline M1-1 & Mechanized & Planted & 47.51 & 34.42 & 18.07 & Loam \\
\hline M1-2 & Mechanized & Planted & 67.40 & 22.60 & 10.00 & Sandy loam \\
\hline M2-1 & Mechanized & 1st ratoon & 36.37 & 40.67 & 22.96 & Loam \\
\hline M2-2 & Mechanized & 1st ratoon & 27.16 & 36.42 & 36.42 & Clay loam \\
\hline M2-3 & Mechanized & 1st ratoon & 44.96 & 33.65 & 21.39 & Loam \\
\hline M3-1 & Mechanized & 2nd ratoon & 54.51 & 27.32 & 18.17 & Sandy loam \\
\hline M3-2 & Mechanized & 2nd ratoon & 21.25 & 51.97 & 26.78 & Silt loam \\
\hline M3-3 & Mechanized & 2nd ratoon & 62.72 & 24.32 & 12.96 & Sandy loam \\
\hline M4-1 & Mechanized & 3rd ratoon & 42.74 & 37.58 & 19.68 & Loam \\
\hline M4-2 & Mechanized & 3rd ratoon & 21.39 & 50.52 & 28.09 & Clay loam \\
\hline L1-1 & Labor & planted & 17.72 & 42.11 & 40.17 & Silt clay loam \\
\hline L2-1 & Labor & 1st ratoon & 25.78 & 35.30 & 38.92 & Clay loam \\
\hline L2-2 & Labor & 1st ratoon & 45.41 & 33.53 & 21.05 & Loam \\
\hline L2-3 & Labor & 1st ratoon & 25.80 & 50.84 & 23.36 & Silt loam \\
\hline L4-1 & Labor & 3rd ratoon & 23.89 & 39.81 & 36.29 & Clay loam \\
\hline L6-1 & Labor & 5 th ratoon & 43.86 & 33.88 & 22.26 & Loam \\
\hline
\end{tabular}




\section{RESULTS}

Soil bulk density: Soil bulk densities varied from 1.24 to $1.78 \mathrm{~kg} \mathrm{~m}^{-3}$. As expected, the mechanized fields had higher values for soil bulk density. The highest value of $1.78 \mathrm{~kg} \mathrm{~m}^{-3}$ was found in a mechanized farming field with a 2nd ratoon crop (M3-3), while the lowest value was recorded in a manual labor farming field with a planted crop $\left(\mathrm{Li}^{-1}\right)$ with $1.24 \mathrm{~kg} \mathrm{~m}^{-3}$.

Cone penetration resistance: To obtain a clearer picture of soil compaction in the field, soil penetration resistance values were plotted as contour lines throughout the soil profile. A natural neighbor model was applied since it shows the boundaries of the surface lines and resulted in a low standard deviation of 0.0496 .

Figure 2 shows the penetration resistance contour lines of the sample in field M4-2 after four years of sugar cane cultivation under mechanized farming. The $\mathrm{x}$-axis distance indicates the horizontal distance measured across a sugarcane row with the sugarcane located at a distance of $100 \mathrm{~cm}$. The lightest color represents the area with the highest value of penetration resistance of the soil (2.8 $\mathrm{MPa}$ in Fig. 2). The penetration resistance values reduce as the color in the contour plot increase, with the lowest value in the black areas being 0.2 MPa. The general characteristics of soil compaction can be observed from the plot of the soil penetration resistance contours. As shown in Fig. 2, soil penetration resistance was higher below a depth of about $45 \mathrm{~cm}$. The highest penetration resistance in this study was 4.8 MPa found in field M1-1 at a distance of $70 \mathrm{~cm}$ and depth of $90 \mathrm{~cm}$. For soil within $45 \mathrm{~cm}$ of the surface, the highest penetration resistance was $4.2 \mathrm{MPa}$ in field M1-1 at a distance of $120 \mathrm{~cm}$ and depth of 32.5 $\mathrm{cm}$ and there were also compacted soil pockets with penetration resistance higher than $2 \mathrm{MPa}$ scattered throughout the soil profiles, especially near the sugarcane row. Figure 2 shows the maximum penetration resistance of $2.8 \mathrm{MPa}$ at position $80 \mathrm{~cm}$ or a $20 \mathrm{~cm}$ distance from the sugarcane row.

On the other hand, the penetration resistance contour lines after labor farming had lower values and were fairly uniform to a depth from the surface of about $45 \mathrm{~cm}$. Furthermore, there were no resistance values higher than $2 \mathrm{MPa}$ (Fig. 3).

In order to characterize soil penetration resistance throughout the soil profiles among the sugarcane fields, each soil profile was divided into 10 sections (Zone1Zone10) as shown in Fig. 4. Zone boundaries were set at a depth of $45 \mathrm{~cm}$ and a width of $40 \mathrm{~cm}$. Average values of penetration resistance in each zone in all samples were calculated and analyzed statistically. The results indicated that there were two different groups of penetration resistance-Zone1 to Zone5 had significantly lower resistance than Zone6 to Zone10 (Table 3). The cone penetration resistance in the sugarcane crops was highest in field M3-1 with a value of $1.86 \mathrm{MPa}$ while field L2-3 recorded the lowest value of $0.51 \mathrm{MPa}$ (Table 4). Sugarcane crops where manual labor had been used had lower cone penetration resistance, with average values not exceeding $1.59 \mathrm{MPa}$.

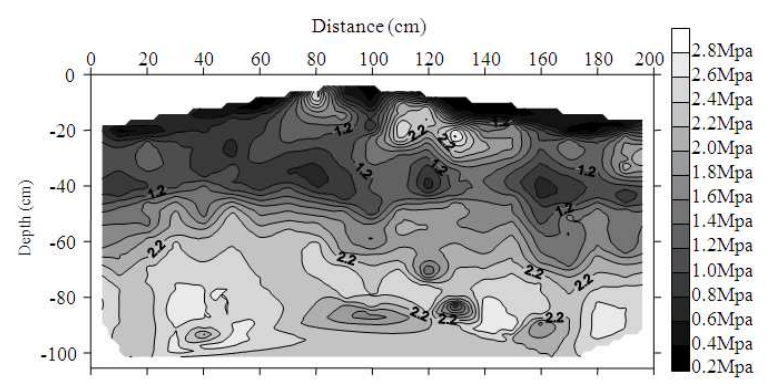

Fig. 2: Soil penetration resistance contour lines after mechanized farming in field M4-2

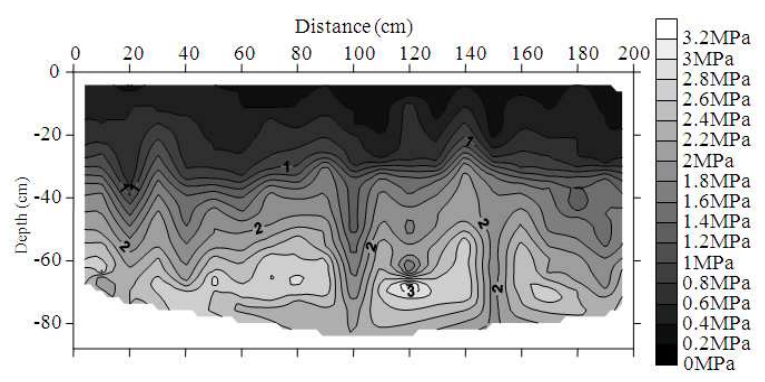

Fig. 3: Soil penetration resistance contour lines after manual labor farming in field L6-1

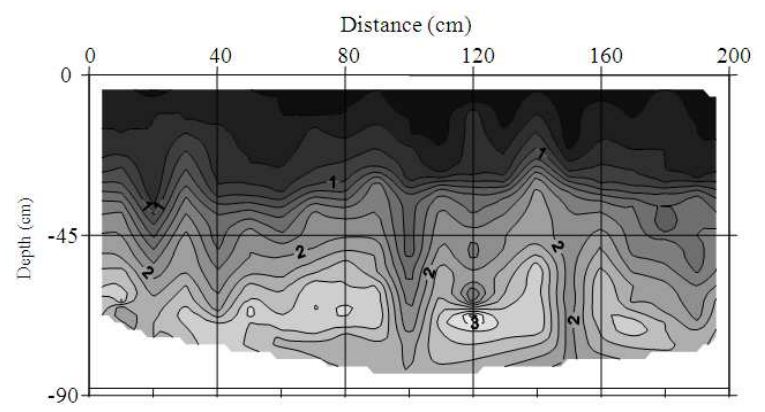

Fig. 4 Division of soil profile into zones 
Am. J. Agri. \& Biol. Sci., 6 (3): 418-422, 2011

Table 2: Soil bulk density results

\begin{tabular}{|c|c|c|c|}
\hline Field code* & 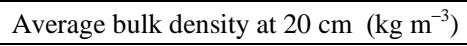 & 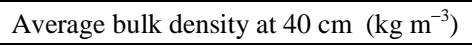 & Average bulk density $\left(\mathrm{kg} \mathrm{m}^{-3}\right)$ \\
\hline$\overline{\mathrm{L} 1-1}$ & $1.24 \mathrm{a}$ & $1.24 \mathrm{a}$ & $1.24 \mathrm{a}$ \\
\hline L2-1 & $1.24 \mathrm{a}$ & $1.24 \mathrm{a}$ & $1.24 \mathrm{a}$ \\
\hline L4-1 & $1.26 \mathrm{a}$ & $1.28 \mathrm{a}$ & $1.27 \mathrm{a}$ \\
\hline M3-2 & $1.37 \mathrm{~b}$ & $1.38 \mathrm{~b}$ & $1.38 \mathrm{~b}$ \\
\hline M4-2 & $1.39 \mathrm{bc}$ & $1.38 \mathrm{~b}$ & $1.39 \mathrm{~b}$ \\
\hline M2-3 & $1.40 \mathrm{bcd}$ & $1.44 \mathrm{bc}$ & $1.42 \mathrm{bc}$ \\
\hline L6-1 & $1.42 \mathrm{bcd}$ & $1.42 \mathrm{bc}$ & $1.42 \mathrm{bc}$ \\
\hline M2-2 & $1.45 \mathrm{cde}$ & $1.43 \mathrm{bc}$ & $1.44 \mathrm{c}$ \\
\hline L2-2 & $1.46 \mathrm{cde}$ & $1.42 \mathrm{bc}$ & $1.44 \mathrm{c}$ \\
\hline L2-3 & $1.47 \mathrm{de}$ & $1.47 \mathrm{~cd}$ & $1.47 \mathrm{c}$ \\
\hline M1-1 & $1.51 \mathrm{ef}$ & $1.52 \mathrm{de}$ & $1.51 \mathrm{~d}$ \\
\hline M4-1 & $1.54 \mathrm{fg}$ & $1.51 \mathrm{de}$ & $1.52 \mathrm{~d}$ \\
\hline M2-1 & $1.54 \mathrm{fg}$ & $1.54 \mathrm{e}$ & $1.54 \mathrm{de}$ \\
\hline M1-2 & $1.58 \mathrm{gh}$ & $1.58 \mathrm{ef}$ & $1.58 \mathrm{ef}$ \\
\hline M3-1 & $1.62 \mathrm{~h}$ & $1.61 \mathrm{f}$ & $1.62 \mathrm{f}$ \\
\hline M3-3 & $1.78 \mathrm{i}$ & $1.78 \mathrm{~g}$ & $1.78 \mathrm{~g}$ \\
\hline
\end{tabular}

\section{DISCUSSION}

Bulk density is dependent on soil texture. Sandy soils have relatively high bulk density since the total pore space in sand is less than that of silt or clay. NRCS Soil Quality Institute (2003) reported that bulk densities that may affect root growth are 1.63, 1.60 and 1.55 $\mathrm{kg} / \mathrm{m}^{3}$ for sandy loam, silt loam and silt clay loam, respectively. Based on these data and the list of soil types in Table 1, most of the mechanized fields in Table 2 have severely affected root growth.

Soil compaction can be caused by natural events such as raindrops, as well as more severely by field operations, such as tillage operations and wheeled traffic. Therefore, compaction may vary depending on the history of operations. As expected, penetration resistance values of soil in the sugarcane fields studied were scattered throughout the soil profile. When considering penetration resistance contours as typically shown in Fig. 2 and 3, a division into two layers can be seen at a depth of about $40-50 \mathrm{~cm}$. Furthermore, statistical analysis confirmed that the value of penetration resistance in the upper layer above $45 \mathrm{~cm}$ and the lower layers at or below this depth were significantly different (Table 3). Since, the conventional plowing depth is about $40 \mathrm{~cm}$, the upper soil is loosened periodically by tillage operations. However, the soil below the tillage layer becomes compacted year by year, resulting in subsoil compaction. In the upper layer, there were some areas at a horizontal distance of $80 \mathrm{~cm}$ and also at 100-140 $\mathrm{cm}$ that showed penetration resistance greater than 2 MPa (Fig. 2). Mari and Changying (2008) stated that the ability of plant roots to penetrate soil is restricted as soil strength increases and Sojka et al. (1990) reported that soil penetration resistance of more than $2 \mathrm{MPa}$ made penetration by the roots very difficult.
Table 3: Cone penetration resistance by zone

\begin{tabular}{ll}
\hline Zone & $\begin{array}{l}\text { Cone penetration } \\
\text { resistance (MPa) }\end{array}$ \\
\hline zone3 & $1.11 \mathrm{a}$ \\
zone2 & $1.11 \mathrm{a}$ \\
zone4 & $1.12 \mathrm{a}$ \\
zone1 & $1.13 \mathrm{a}$ \\
zone5 & $1.16 \mathrm{a}$ \\
zone8 & $1.95 \mathrm{~b}$ \\
zone6 & $1.96 \mathrm{~b}$ \\
zone10 & $1.96 \mathrm{~b}$ \\
zone7 & $1.98 \mathrm{~b}$ \\
zone9 & $2.00 \mathrm{~b}$ \\
\hline
\end{tabular}

Remark: Figures in the same column with the same lower case letter are not significantly different by Duncan's multiple range test at 95\% significance level

Table 4: Cone penetration resistance by field

\begin{tabular}{ll}
\hline Field code & $\begin{array}{l}\text { Cone penetration } \\
\text { resistance (MPa) }\end{array}$ \\
\hline L2-3 & $0.51 \mathrm{a}$ \\
M1-2 & $0.70 \mathrm{~b}$ \\
M2-3 & $1.17 \mathrm{c}$ \\
L2-1 & $1.32 \mathrm{~d}$ \\
L1-1 & $1.41 \mathrm{de}$ \\
L4-1 & $1.46 \mathrm{e}$ \\
M1-1 & $1.51 \mathrm{ef}$ \\
L6-1 & $1.53 \mathrm{ef}$ \\
L2-2 & $1.59 \mathrm{fg}$ \\
M4-1 & $1.60 \mathrm{fg}$ \\
M2-2 & $1.60 \mathrm{fg}$ \\
M3-2 & $1.63 \mathrm{fg}$ \\
M3-3 & $1.69 \mathrm{gh}$ \\
M2-1 & $1.77 \mathrm{hi}$ \\
M4-2 & $1.80 \mathrm{hi}$ \\
M3-1 & $1.86 \mathrm{i}$ \\
\hline
\end{tabular}

Remark: Figures in the same column with the same lower case letter are not significantly different by Duncan's multiple range test at 95\% significance level

The greater penetration resistance around $100-140 \mathrm{~cm}$ horizontally and at a depth of about $20-30 \mathrm{~cm}$ seems to have been caused by forces acting on the ground due to 
the continuous or repeated tracking of agricultural machinery. Radcliffe et al. (1988) reported that the soil at a depth of $15-30 \mathrm{~cm}$ from the surface under tractor wheels will be compressed more than at the same depth with no tractor activity. However, the higher soil penetration resistance in soil near the surface at a horizontal distance of $80 \mathrm{~cm}$ may have been due to other causes, perhaps related to changes in soil conditions after flooding and then subsequent drying.

In general, the fields treated using mechanized farming seemed to showed higher values of both bulk density and cone penetration resistance when compared with the fields under manual labor farming. The highest value of bulk density found in a mechanized farming field (M3-3) was 44.4\% higher than the lowest value found in a manual labor field (L1-1). In addition, it is of interest that the bulk density in a field farmed using manual labor with a 5th ratoon crop (L6-1), which was the highest ratoon crop used in this research, was $21 \%$ lower than the highest value. On average, the bulk densities of soil in mechanized farming fields were $12.6 \%$ significantly higher than in manual labor farming fields. The highest value of penetration resistance in a mechanized field (M3-1) was 264.7\% higher than the lowest resistance in a manual labor field (L2-3) and the average value for the mechanized field treatments was $23.3 \%$ higher than for the manual labor treatments.

\section{CONCLUSION}

\section{Based on the results of this research:}

- The average bulk density of soil in mechanized farming fields was $12.6 \%$ significantly higher than in manual labor farming fields. Moreover, most of mechanized fields were in a state where there was severe impairment to root growth

- Soil penetration resistance contours can provide a useful visual presentation of soil compaction throughout the soil profile

- The average value of soil penetration resistance in mechanized farming field was $23.3 \%$ higher than in manual labor farming fields

- The soil penetration resistance in manual labor farming fields at soil depths to about $45 \mathrm{~cm}$ was more uniformly distributed than in mechanized farming fields

\section{ACKNOWLEDGEMENT}

The researcher gratefully acknowledge the Thai Research Fund (TRF) for financial support.

\section{REFERENCES}

Alakukku, L. and P. Elonen, 1995. Long-term effects of a single compaction by heavy field traffic on yield and nitrogen uptake of annual crops. Soil Tillage Res., 37: 141-152. DOI: 10.1016/01671987(95)00503-X

CAI, 2008. Agricultural Statistics of Thailand, Crop Year 2008. Centre for Agricultural Information, Office of Agricultural Economics, Ministry of Agriculture and Cooperatives, Bangkok, Thailand, pp: 169.

Cane and Sugar Industry Policy Bureau, 2006. Sugarcane and Sugar Industry and Renewable Energy Production.

Grange, I., P. Prammanee and P. Prasertsak, 2005. Comparative analysis of different tillage systems used in sugarcane (Thailand). AFBM J., 2: 46-50.

Land Development Department, 2009. Hardpan in Thailand.

Mari, G.R. and J. Changying, 2008. Influence of agricultural machinery traffic on soil compaction patterns, root development and plant growth, overview. American-Eurasian J. Agric. Environ. Sci., 3: 49-62.

Mitr Phol Group, 2011. Sugarcane production in Thailand.

NRCS Soil Quality Institute, 2003. Soil Quality Agronomy Technical Note No. 17. United States Department of Agriculture, Agricultural Research Service and Natural Resources Conservation Service.

Office of the Cane and Sugar Board, 2008. Report of sugarcane production area in year 2007/2008.

Radcliffe, D.E., G. Manor, G.W. Langdale, L. Clark and R.R. Bruce, 1988. Effect of traffic and tillage on mechanical impedance in a layered soil. USDAARS, Watkinsville, GA, pp: 30-33.

Sojka, R.E., W.J. Busscher, D.T. Gooden and W.H. Morrison, 1990. Subsoiling for sunflower production in the southeast Coastal Plains. Soil. Sci.. Soc. Am. J. 4: 1107-1112.

Udon-City.Com, 2011. Measures to increase cassava productivity.

Usaborisut, P. and T. Niyamapa, 2010. Effects of machine-induced soil compaction on growth and yield of sugarcane. Am. J. Agrc. Biol. Sci., 3: 269-273. DOI: 10.3844/ajabssp.2010.269.273 